\title{
A study of the stable carbon and oxygen isotope composition of recent shells of Mytilidae, especially of oxygen values in relation to temperature
}

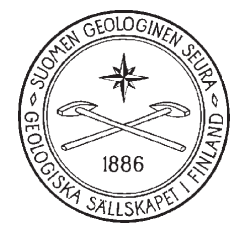

\author{
Joakim Donner ${ }^{1)}$, Eloni Sonninen ${ }^{2)}$, Juha Karhu ${ }^{3)}$ \\ and Aarno Kotilainen ${ }^{4)}$ \\ 1) Pohjoisranta $12 \mathrm{~A} \mathrm{1,} \mathrm{Fi-00170} \mathrm{Helsinki,} \mathrm{Finland}$ \\ 2) Laboratory of Chronology, Finnish Museum of Natural History, P.O. Box 64, \\ Fi-00014 University of Helsinki, Finland \\ 3) Department of Geosciences and Geography, Division of Geology, P.O. Box 64, \\ Fi-00014 University of Helsinki, Finland \\ 4) Geological Survey of Finland, P.O. Box 96, Fi-02151 Espoo, Finland
}

\begin{abstract}
Analyses of the stable isotopes ${ }^{18} \mathrm{O}$ and ${ }^{13} \mathrm{C}$ were made of modern marine shells of the widely distributed Mytilidae, primarily intertidal species, collected from beaches in Europe and southern Africa, as well as from Australia and Argentina. At sites facing the open sea and where the field data of annual mean sea-surface temperatures have been recorded a comparison could be made between the stable isotope values of the shells and the seawater temperatures. The comparison shows that there is a good negative correlation between the seawater temperatures and the $\delta^{18} \mathrm{O}$ values of the Mytilidae shells.

The analyses of a series of samples from the outer layer of the valves from five different sites, at right angles to the annual increments, reflected the seasonal variations of the seawater temperatures. The recorded amplitudes of the isotope temperatures in the shells based on the $\delta^{18} \mathrm{O}$ values were similar to the amplitudes of the recorded seasurface temperatures just outside the beaches, except for Choromytilus in Swakopmund where the relatively shallow water outside the beach was more influenced by the seasonal temperature changes than the seawater outside the coast.
\end{abstract}

Results shown here from the globally distributed records from the Northern and Southern Hemispheres confirm the universal use of stable isotopes $\left({ }^{18} \mathrm{O}\right)$ of marine shells (Mytilidae) in palaeoclimatological / -oceanographical studies.

Keywords (GeoRef Thesaurus, AGl): stable isotopes, Mollusca, shells, Mytilidae, sea water, paleotemperature, Holocene

Corresponding author (e-mail: joakim.donner@saunalahti.fi)

Editorial handling: Joonas Virtasalo (joonas.virtasalo@gtk.fi) 


\section{Introduction}

The present contribution is a continuation and reinterpretation of earlier studies of carbon and oxygen stable isotopes of resent Mytilidae shells from sites in North Norway (Donner \& Nord, 1986) and southern Africa (Donner \& Billström, 1988; Talma et al., 1992), with shells from other areas included. The emphasis is on the relationship between the ${ }^{18} \mathrm{O}$ content of shells collected from beaches and recorded temperatures of the surface water outside the beaches. The aim is to provide additional information for paleo-oceanographic studies of marine shells from coastal sites. The study differs from the later study by Wanamaker et al. (2007) in which the relationship between the oxygen isotopes of recent shells of Mytilus edulis and temperature was based on experiments.

The isotopic composition of the shells of marine molluscs reflects the composition and temperature of the water in which they live as they precipitate their carbonate in isotopic equilibrium with the water (Epstein et al., 1953). In the study of the relationship between the ${ }^{18} \mathrm{O}$ content of seawater with that of the carbonates in modern marine shells the widely distributed Common Mussel Mytilus edulis has been shown to be ideal in the study of near-shore temperatures of the surface water (Wanamaker et al., 2007). By using average samples from entire shell valves it is possible to compare their $\delta^{18} \mathrm{O}$ values with recorded seawater temperatures. In addition, $\delta^{18} \mathrm{O}$ values of samples taken from the outer layer of the valves across the central axis at right angles to the annual growth increments record the annual temperature fluctuations. The seasonal temperature fluctuations are also recorded in the oxygen isotopic composition of planktonic foraminifera in the near-surface seawater, but the use of these fluctuations in the reconstruction of palaeotemperatures is restricted because the isotope record in deep-sea cores with a longer time scale is dominated by changes in the volume of the continental ice sheets during the Pleistocene glaciations (Shackleton, 1967; Shackleton, 1987; Dansgaard \& Tauber, 1969). This also restricts the use of Mytilus shells to the Holocene in reconstructions of palaeotemperatures. The present study, however, deals only with the stable isotopes in modern shells.

In connection with the use of radiocarbon dating of Holocene shells from North Norway (Donner el al., 1977) and Australia (Donner \& Jungner, 1981) modern shells were collected of Mytilidae which, according to Kilburn \& Rippey (1982), are probably the most abundant intertidal bivalves on rocky shores throughout the world, Mytilus edulis being one of the species in the family. The shells from North Norway were later used for studies of their carbon and oxygen stable isotope values (Donner \& Nord, 1986) as well as shells collected from southern Africa, i.e. South Africa and Namibia (Donner \& Billström, 1988; Talma et al., 1992). In addition, stable isotope determinations were made of recent Mytilidae bivalves collected from beaches in Europe, as well as from Tierra del Fuego in Argentina (collected by R. Maud, South Africa).

The ${ }^{13} \mathrm{C}$ content of the carbonate in the shells reflects essentially the dissolved inorganic carbon (DIC) in seawater, but also other variables like metabolic carbon, and is influenced to a lesser degree by the temperature (Talma et al., 1993). In addition, in estuaries with a mixture of freshwater with seawater the ${ }^{13} \mathrm{C}$ content of the shells is lower than in marine shells from an open coast, which led to the use of the relation between the ${ }^{13} \mathrm{C}$ and ${ }^{18} \mathrm{O}$ values in reconstructing the isotopic temperatures (Mook \& Vogel, 1968; Mook, 1971), a relation used for the shells from North Norway (Donner \& Nord, 1986). The study of Wanamaker et al. (2007), however, shows that the $\delta^{18} \mathrm{O}$ values alone reliably record the water temperatures.

\section{Analysed shells and methods}

Most of the Mytilidae valves used consist of an outer layer of prismatic calcite, with clear annual growth increments, and an inner layer of mainly nacreous aragonite (Carter, 1980). The only Mytilidae species used, which consists entirely of aragonite, is Perna perna from the comparatively warm waters by the 
coast of southern Africa east of Cape Town. This is in keeping with the demonstration by Lowenstam (1954) that Mytilus edulis valves have higher percentages of aragonite with the increase in temperatures of the warmest months. No effect related to the relative fractionation of calcite and aragonite between the inner and outer layers of the valves could, however, be demonstrated in the study of the shells from southern Africa (Talma et al., 1992).

Table 1 gives the coordinates for the sites of analysed Mytilidae shells and Fig. 1 their spatial distribution. The shells used are listed in Table 2 with references to publications in which their stable isotopes have earlier been discussed. The years when the shells were collected are also given in Table 2. The warm-water Brown Mussel Perna perna is the dominant species on the intertidal rocky shores of southern Africa, except in the colder waters in Southwestern Cape where the Black Mussel Choromytilus meridionalis replaces it (Kilburn \& Rippey, 1982). The mid-tide Edible Mussel Mytilus planulatus in Australia is similar to the Common Mussel Mytilus edulis (Child, 1977), which has a wide distribution along the Atlantic coasts, in the western Atlantic
Table 1. List of sites with coordinates and of annual mean sea-surface temperatures.

\begin{tabular}{|c|c|c|c|c|}
\hline \multicolumn{2}{|c|}{ Site } & \multirow{2}{*}{$\begin{array}{l}\text { Latitude* } \\
27.5678 \text { S }\end{array}$} & \multirow{2}{*}{$\begin{array}{l}\text { Longitude* } \\
32.6799 \text { E }\end{array}$} & \multirow{2}{*}{$\begin{array}{l}\text { SST } \\
\left({ }^{\circ} \mathrm{C}\right) \\
23.5\end{array}$} \\
\hline I. & Sodwana Bay, South Africa & & & \\
\hline 2. & Durban, South Africa & $29.8422 \mathrm{~S}$ & $31.0366 \mathrm{E}$ & 22.7 \\
\hline 3. & $\begin{array}{l}\text { Port Elizabeth, Hougham } \\
\text { Park, South Africa }\end{array}$ & $33.7592 \mathrm{~S}$ & $25.7485 \mathrm{E}$ & 18.0 \\
\hline 4. & Plettenberg Bay, South Africa & $34.0555 \mathrm{~S}$ & $23.3777 \mathrm{E}$ & 17.3 \\
\hline 5. & Mossel Bay, South Africa & $34.1745 \mathrm{~S}$ & $22.1390 \mathrm{E}$ & 17.3 \\
\hline 6. & Kanonstrand, South Africa & $34.327 \mathrm{I} \mathrm{S}$ & $21.3433 \mathrm{E}$ & 17.3 \\
\hline 7. & Bloubergstrand, South Africa & $33.7958 \mathrm{~S}$ & $18.3380 \mathrm{E}$ & 14.3 \\
\hline 8. & Swakopmund, Namibia & $22.6592 \mathrm{~S}$ & I4.5323 E & 16.0 \\
\hline 9. & Cullendulla Creek, Australia & $35.7060 \mathrm{~S}$ & I50.209| E & \\
\hline & $\begin{array}{l}\text { Havningberg, Norway } \\
\text { (Varanger peninsula) }\end{array}$ & $70.5414 \mathrm{~N}$ & $30.6070 \mathrm{E}$ & 5.3 \\
\hline & $\begin{array}{l}\text { Kjølneset, Norway } \\
\text { (Varanger peninsula) }\end{array}$ & $70.8593 \mathrm{~N}$ & $29.2282 \mathrm{E}$ & \\
\hline 12. & Valset, Norway (Trondheim) & $63.6428 \mathrm{~N}$ & $09.6921 \mathrm{E}$ & 8.3 \\
\hline & Strandhill, Co. Sligo, Ireland & $54.2782 \mathrm{~N}$ & $08.5978 \mathrm{~W}$ & \\
\hline & Oban, Scotland & $56.4118 \mathrm{~N}$ & $05.4776 \mathrm{~W}$ & \\
\hline 15. & Yorkshire, Bridlington, England & $54.0849 \mathrm{~N}$ & $00.2065 \mathrm{~W}$ & \\
\hline & Petten, The Netherlands & $52.7805 \mathrm{~N}$ & $04.6627 \mathrm{E}$ & \\
\hline & Royan, France & $45.6258 \mathrm{~N}$ & $01.0201 \mathrm{~W}$ & \\
\hline & $\begin{array}{l}\text { Beagle Channel, Argentina, } \\
\text { Tierra del Fuego }\end{array}$ & $54.9495 \mathrm{~S}$ & $66.8586 \mathrm{~W}$ & 6.5 \\
\hline
\end{tabular}

* Coordinates (latitude and longitude) are shown in Degrees and in Decimal Degrees.

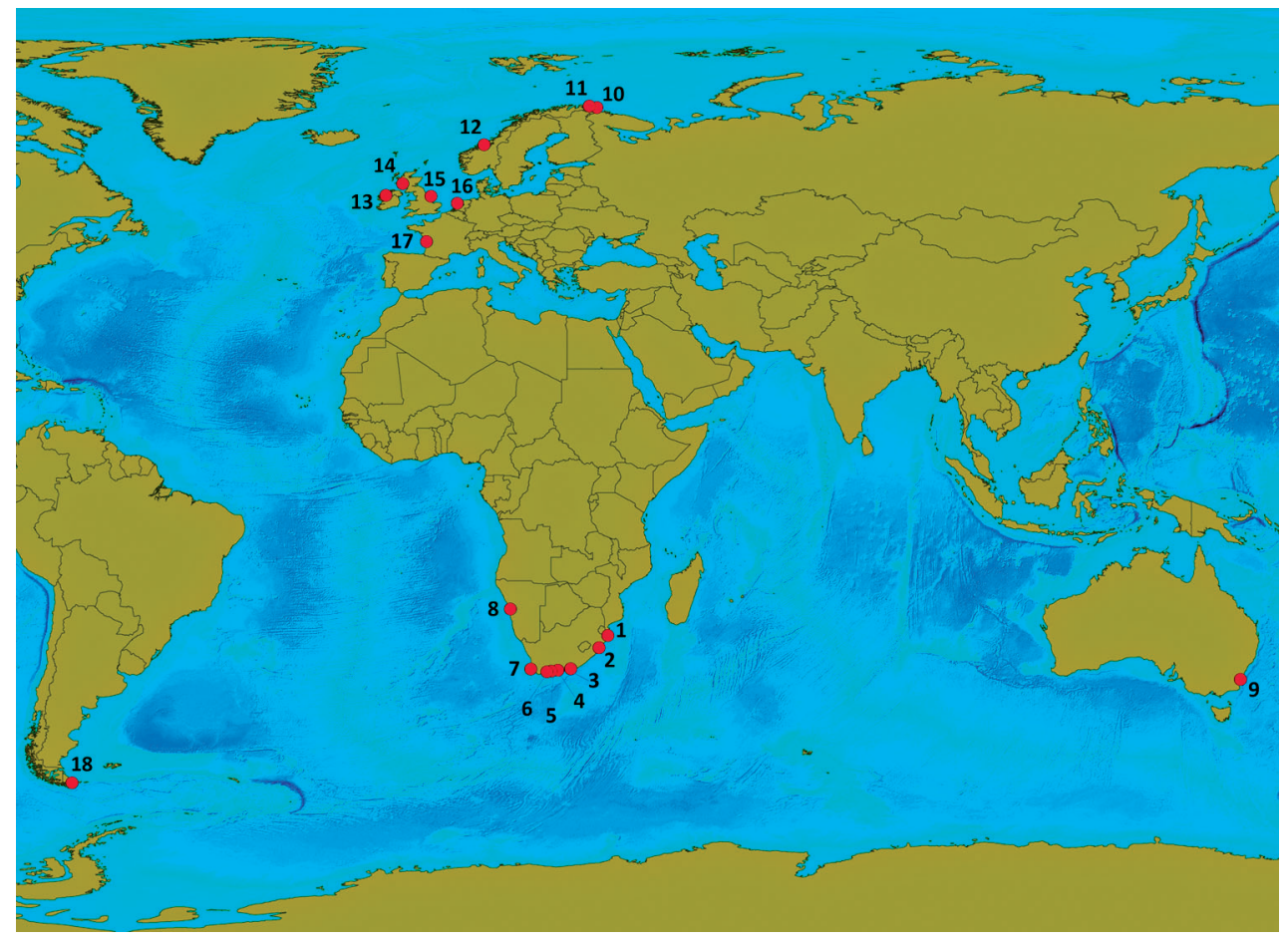

Fig. 1. Map showing the locations of sites for analysed shells. 
Table 2. Mean stable isotope values of analysed Mytilidae shells.

\begin{tabular}{|c|c|c|c|c|c|c|}
\hline Site & Species & $\delta^{13} \mathrm{C} \%$ & $\pm s t d$ & $\delta^{18} \mathrm{O} \%$ & $\pm s t d$ & n \\
\hline \multicolumn{7}{|l|}{ Southern Africa ${ }^{1, a}$} \\
\hline Sordwana Bay 1987 & Perna perna & 0.43 & 0.47 & -1.07 & 0.12 & 3 \\
\hline Durban 1985 & Perna perna & 0.70 & 0.19 & -0.65 & 0.16 & 3 \\
\hline PE, Hougham Park I 987 & Perna perna & 0.65 & 0.38 & 0.20 & 0.14 & 3 \\
\hline PE, Brighton Beach 1985 & Perna perna & -0.76 & 0.25 & -0.18 & 0.15 & 3 \\
\hline PE, Cape Recife 1987 & Perna perna & 0.74 & 0.65 & 0.11 & 0.07 & 3 \\
\hline Plettenberg Bay 1987 & Perna perna & -0.43 & 0.86 & -0.16 & 0.11 & 3 \\
\hline Mossel Bay 1987 & Perna perna & 0.97 & 0.17 & 0.19 & 0.19 & 3 \\
\hline Kanonstrand 1987 & Perna perna & 0.66 & & -0.52 & & 2 \\
\hline Bloubergstrand 1985 & Choromytilus meridionalis & -0.06 & 0.12 & 0.53 & 0.11 & 3 \\
\hline Swakopmund I985 & Choromytilus meridionalis & -0.70 & 0.30 & 0.41 & 0.05 & 3 \\
\hline \multicolumn{7}{|l|}{ Australia ${ }^{2, b}$} \\
\hline Cullendulla Creek, NSW 1979 & Mytilus planulatus & 0.98 & & -0.81 & & I \\
\hline \multicolumn{7}{|l|}{ Norway, Varanger peninsula ${ }^{3}$} \\
\hline Havningberg (IX) 1982 & Modiolus modiolus & 1.27 & 0.18 & 2.87 & 0.13 & 3 \\
\hline KjøIneset (XIII) I982 & Modiolus modiolus & 0.73 & 0.17 & 3.01 & 0.06 & 3 \\
\hline \multicolumn{7}{|l|}{ Norway, Trondheim ${ }^{3}$} \\
\hline Valset, Agdenes 1995 & Modiolus modiolus & 0.49 & & 1.05 & & 2 \\
\hline Valset, Agdenes 1995 & Mytilus edulis & 0.31 & & 1.06 & & 2 \\
\hline \multicolumn{7}{|l|}{ Ireland ${ }^{2}$} \\
\hline Strandhill, Co. Sligo I982 & Mytilus edulis & -0.64 & 0.19 & 0.88 & 0.18 & 3 \\
\hline \multicolumn{7}{|l|}{ Scotland ${ }^{2}$} \\
\hline Oban 1956 & Mytilus edulis & 0.45 & & 0.27 & & I \\
\hline \multicolumn{7}{|l|}{ England $^{2}$} \\
\hline Yorkshire, Bridlington 1992 & Mytilus edulis & 0.54 & & 0.89 & & I \\
\hline \multicolumn{7}{|l|}{ The Netherlands ${ }^{2}$} \\
\hline Petten 1996 & Mytilus edulis & -1.39 & & -0.67 & & I \\
\hline \multicolumn{7}{|l|}{ France $^{2}$} \\
\hline Royan 1967 & & -1.19 & & -1.69 & & I \\
\hline \multicolumn{7}{|l|}{ Argentina, Tierra del Fuego ${ }^{3, *}$} \\
\hline Beagle Channel 1993 & Mytilus edulis & 0.74 & & 0.92 & & I \\
\hline Beagle Channel 1993 & Mytilus edulis & 0.77 & & 1.06 & & I \\
\hline
\end{tabular}

Analysis performed 'A. S. Talma, ${ }^{2}$ E. Sonninen, ${ }^{3}$ J. A. Karhu References: ${ }^{\mathrm{a} T a}$ alma, Donner \& Ellis 1992, 'bonner \& Jungner 198I, 'Donner \& Nord 1986 ${ }^{*}$ Coll. R. Maud

Ocean as well as along the European coasts, where there is a great temperature range (Wanamaker et al., 2007). The Horse Mussel Modiolus modiolus lives in deeper water than the Common Mussel, preferring stony sea beds at 5-60 m depth (Møller Christensen \& Dance, 1980).

Samples for the analyses of the average isotopic composition of whole shells were taken by drilling with a $1 \mathrm{~mm}$ dental drill a series of holes along the valves, after they had been cleaned. The $\delta^{18} \mathrm{O}$ and $\delta^{13} \mathrm{C}$ values given in Table 2 for the sites in southern
Africa, and Trondheim in Norway are averages of analyses of 2-3 valves, for the site in Ireland they are an average of three analyses of one valve and for the other sites analyses of only one valve (Table 2). For the analyses of the seasonal isotopic variations samples were taken from the outer layers of five valves (Table 3) along the growth increments, starting from the second to the fourth annual increment from the umbo.

Many of the shells used were dealt with in earlier studies, in some of which the stable isotopes were 
Table 3. Stable isotope variations within individual valves.

\begin{tabular}{|c|c|c|c|}
\hline Site & Species & $\delta^{13} \mathrm{C} \%$ & $\delta^{18} \mathrm{O} \%$ \\
\hline \multicolumn{4}{|l|}{ Southern Africa ${ }^{1, a}$} \\
\hline Sordwana Bay 1987 & Perna perna & 0.88 & -1.56 \\
\hline \multirow[t]{13}{*}{ Samples $3.7-7.5 \mathrm{~cm}$ from umbo } & & 0.83 & -0.95 \\
\hline & & 0.71 & -0.81 \\
\hline & & 0.55 & -0.83 \\
\hline & & 0.62 & -0.93 \\
\hline & & 0.55 & -1.21 \\
\hline & & 0.55 & -1.13 \\
\hline & & 0.60 & -1.34 \\
\hline & & 0.47 & $-|.4|$ \\
\hline & & 0.52 & -1.18 \\
\hline & & 0.05 & -0.83 \\
\hline & & 0.84 & -0.31 \\
\hline & & 0.21 & -1.36 \\
\hline & & 0.61 & -2.06 \\
\hline Swakopmund 1985 & Choromytilus meridionalis & -0.82 & 0.97 \\
\hline \multirow[t]{9}{*}{ Samples $5.0-8.7 \mathrm{~cm}$ from umbo } & & -1.09 & -0.07 \\
\hline & & -1.0 & 0.92 \\
\hline & & -0.94 & 0.66 \\
\hline & & -1.2 & 0.64 \\
\hline & & -1.25 & 0.21 \\
\hline & & -1.14 & 0.39 \\
\hline & & -0.82 & 0.91 \\
\hline & & $-1.0 \mid$ & -0.4 \\
\hline & & -1.06 & 0.5 \\
\hline \multicolumn{4}{|l|}{ Norway } \\
\hline Valset $1995^{2}$ & Modiolus modiolus & -0.15 & 1.78 \\
\hline \multirow[t]{12}{*}{ Samples $2.3-5.6 \mathrm{~cm}$ from umbo } & & 0.13 & 0.8 \\
\hline & & -0.43 & 0.75 \\
\hline & & 0.01 & 0.99 \\
\hline & & 0.26 & 1.72 \\
\hline & & 0.33 & 0.44 \\
\hline & & 0.19 & 0.25 \\
\hline & & -0.68 & 0.16 \\
\hline & & -0.35 & 0.96 \\
\hline & & -0.72 & 0.81 \\
\hline & & -0.29 & 0.67 \\
\hline & & $-0.7 \mid$ & 1.16 \\
\hline & & -0.2 & 1.65 \\
\hline Kjølneset (XIII) $1982^{3}$ & Modiolus modiolus & 0.2 & 1.0 \\
\hline \multirow[t]{8}{*}{ Samples $3.7-5.6 \mathrm{~cm}$ from umbo } & & 0.1 & 1.2 \\
\hline & & 0.1 & 1.7 \\
\hline & & 0.1 & 1.6 \\
\hline & & 0.2 & I.I \\
\hline & & 0.0 & 1.7 \\
\hline & & 0.4 & 2.0 \\
\hline & & 0.3 & $\mathrm{I} .5$ \\
\hline & & 0.2 & 1.9 \\
\hline Havningberg (IX) $1982^{3}$ & Modiolus modiolus & 1.3 & 1.3 \\
\hline \multirow[t]{4}{*}{ Samples $3.0-5.0 \mathrm{~cm}$ from umbo } & & 1.2 & 2.4 \\
\hline & & 1.2 & 2.2 \\
\hline & & 1.3 & 2.2 \\
\hline & & 1.3 & 1.5 \\
\hline
\end{tabular}

Analysis performed 'A.S. Talma, ${ }^{2}$ E. Sonninen, ${ }^{3}$ A.G. Nord References: ${ }^{\mathrm{T}}$ Talma, Donner \& Ellis 1992 analysed. In addition, the Mytilidae shells were separately collected at sites visited for various studies, the earliest in Norway and Ireland 1982. The isotope analyses were therefore, understandably, done in different laboratories at different times between 1983 and 2007. The shells from the Varanger peninsula and Trondheim in Norway, as well as the shells from Tierra del Fuego in Argentina, were analysed at the Geological Survey of Finland, the shells from southern Africa in the Quaternary Dating Research Unit, CSIR, Pretoria (Talma et al., 1992) and the shell from Australia and the shells from Ireland, Scotland, England, the Netherlands and France at the Laboratory of Chronology of the Finnish Museum of Natural History, University of Helsinki (formerly the Radiocarbon Dating Laboratory). The shells from the Varanger peninsula in Norway used for the study of the seasonal isotopic variations were analysed at the Laboratory for Isotope Geology, Swedish Museum of Natural History in Stockholm (Donner \& Nord, 1986) and those from southern Africa in Pretoria.

The carbonate powder from the shells was pre-treated in vacuum in the above-mentioned laboratories at $400-450{ }^{\circ} \mathrm{C}$ to remove organic material, and reacted with $95-102$ $\%$ phosphoric acid at $25^{\circ} \mathrm{C}$ to produce carbon dioxide. The isotope analyses were performed with the mass spectrometers in use at the laboratories. The isotope data are given as $\delta$ values in per mille relative to VPDB and were calibrated using an international carbonate reference NBS19 (NBS20 in one laboratory). 
The analytical precisions given by the four laboratories were between $\pm 0.2 \%$ and $\pm 0.07 \%$ o for $\delta^{18} \mathrm{O}$ and between $\pm 0.1 \%$ and $\pm 0.04 \%$ o for $\delta^{13} \mathrm{C}$ values. A new recommendation for normalizing $\delta^{13} \mathrm{C}$ values (Coplen et al., 2006) by anchoring the other end to a low $\delta^{13} \mathrm{C}$ value (LSVEC) was not utilized while most of $\delta^{13} \mathrm{C}$ data were here produced before the recommendation. Both $\delta^{13} \mathrm{C}$ and $\delta^{18} \mathrm{O}$ values of shell samples are close to the values of the international reference carbonate NBS19 $\left(\delta^{13} \mathrm{C}=+1.95 \%\right.$ and $\delta^{18} \mathrm{O}=-2.2 \%$ o used for calibration.

In the comparison of the isotope composition of the analysed Mytilidae shells with average seawater temperatures the coastal waters of southern Africa are particularly suitable because of the comparatively great range of recorded temperatures. The temperatures listed in Table 1 are annual mean seasurface temperatures for the period 1968-1978 (Christensen, 1980), slightly different from those earlier used based partly on observations made by the South African Weather Bureau (Talma et al., 1992). The seawater temperatures for Norway (Table 1) are annual mean temperatures for the period 1936-1970 recorded at $4 \mathrm{~m}$ depth by coastal liners (Midttum, 1975). The mean seawater temperature quoted for Tierra del Fuego is that provided by R. Maud (pers. commun.).

The oxygen isotope compositions of the analysed Mytilidae valves only represent averages for a few years of growth preceding the years when the fresh shells were collected from the beaches. The quoted temperatures for the seawater in Table 1, on the other hand, are means for many years, for southern Africa 10 years and for Norway 34 years, in both cases for periods before the shells were collected (Table 2). For this reason, a very detailed comparison of the oxygen isotope values of the analysed shells with the seawater temperatures was not possible.

\section{Results and discussion}

Some of the Mytilidae shells studied are from coasts where the ocean water is mixed with fresh water from rivers. In studies of shells from Dutch estuaries
Mook \& Vogel (1968) and Mook (1971) demonstrated the influence of this mixing. These results were then applied in the study of the isotope values of shells of Mytilus and Modiolus from the coast of the Varanger peninsula in North Norway (Donner \& Nord, 1986). The temperature scale used was based on the equation $\mathrm{t}=16.9-4.2$ $\left(\delta_{\mathrm{PDB}}^{18}-\delta_{\mathrm{SMOV}}^{18}\right)+0.13\left(\delta_{\mathrm{PDB}}^{18}-\delta_{\text {SMOV }}^{18}\right)^{2}$ by Epstein et al. (1953) as modified by Craig (1965) and used by Mook (1971), where $t$ is in degrees Celcius, $\delta_{\mathrm{PDB}}^{18}$ and $\delta_{\text {SMOV }}^{18}$ in $\%$ refer to the ${ }^{18} \mathrm{O}$ content of the sample and the water (Standard Mean Ocean Water).

In the preliminary presentation of the results of the analyses of stable isotopes of shells from the coast of southern Africa the same equation was used (Donner \& Billström, 1988), assuming that the $\delta^{13} \mathrm{C}$ values gave some indication of the influence of fresh water from the rivers. Some of the analysed samples consisted of aragonite and a temperature scale for aragonite was therefore included, using the different fractionation values reported for calcite and aragonite by Rubinson \& Clayton (1969). In the later more extensive study of recent shells, mostly of Mytilidae, collected from the southern African coast (Talma et al., 1992), it was concluded that the isotope differences were not related to differences in shell mineralogy, i.e. to the relative fractionation effects of calcite and aragonite. It was also concluded that as there was generally no influence of fresh water having diluted the seawater along the southern African coast with its rough seas the comparison of the isotope composition of the shells with seawater temperatures could be based only on the $\delta^{18} \mathrm{O}$ values (Talma et al., 1992). The average $\delta^{18} \mathrm{O}$ values of the analysed shells followed the pattern of lower values for increased seawater temperatures, shown in a diagram comparing the relation between average ${ }^{18} \mathrm{O}$ content of shells and estimated average seawater temperatures of the sites used. In the comparison of the $\delta^{18} \mathrm{O}$ values with the calibration line based on the above-mentioned equation modified by Craig (1965) the values of Perna perna fitted well with the line, whereas the values of the cold-water species of Choromytilus meridionalis, all about $+0.5 \%$, were seemingly independent of the mean seawater 
temperatures of the sites. A predominantly summer growth was mentioned as a possible reason for the isotopic temperatures being higher than the annual seawater temperatures, but as there was a lack of a temperature relation of the species it was considered unreliable for temperature determinations (Talma et al., 1992).

Even if there was not a relation between the $\delta^{18} \mathrm{O}$ values of Choromytilus from southern Africa with the calibration line used, the approach in the study by Talma et al. (1992) differed from the earlier studies of shells from southern Africa (Donner \& Billström, 1988) and from North Norway (Donner \& Nord, 1986). In them the calculated temperatures were based on both $\delta^{18} \mathrm{O}$ and $\delta^{13} \mathrm{C}$ values, assuming that there was an influence of fresh water on the seawater at the coasts. Detailed studies of how ${ }^{13} \mathrm{C}$ is incorporated into Mytilus edulis shells have shown that the shell $\delta^{13} \mathrm{C}$ values are not generally suitable for environmental reconstructions, whereas there is a clear relationship between the $\delta^{18} \mathrm{O}$ values and temperature for Mytilus edulis studied from Greenland and Maine grown from $4-19{ }^{\circ} \mathrm{C}$ in three salinity conditions (Wanamaker et al., 2007).

When all $\delta^{18} \mathrm{O}$ and $\delta^{13} \mathrm{C}$ values for Mytilidae in the present study (Table 2) are shown in a scatter diagram (Fig. 2) there is a weak positive correlation between them, with a great scatter of the data as expected from earlier results (Wanamaker et al 2007). The linear correlation does, however, show an increase of $\delta^{18} \mathrm{O}$ values with an increase in $\delta^{13} \mathrm{C}$ values, in keeping with a similar correlation diagram represented for Mytilus by Wanamaker et al. (2007). In the diagram showing the relation between observed temperatures of the seawater and the $\delta^{18} \mathrm{O}$ values (Fig. 3), only shells from open coasts with records of mean temperatures were used (Table 1). In this way the possible effect of fresh water from rivers and in estuaries on the isotope ratios of the shells was minimised.

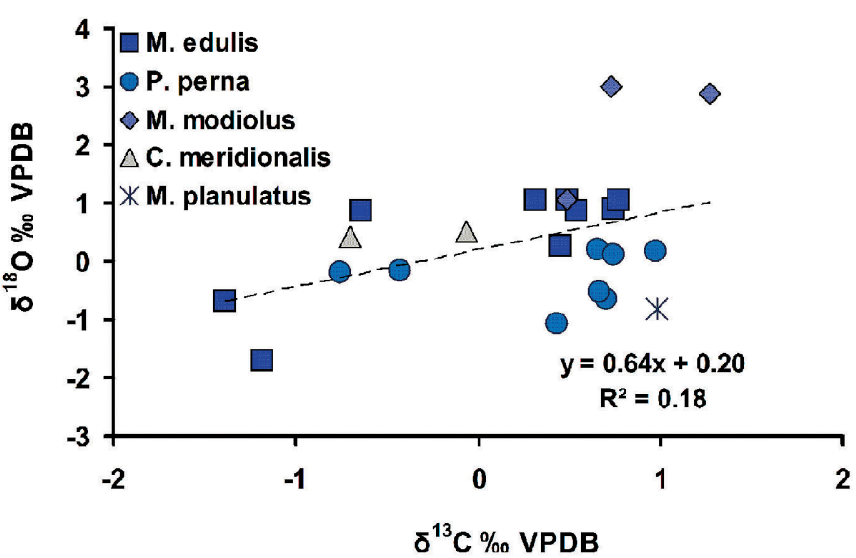

Fig. 2. Relationship between $\delta^{18} \mathrm{O}$ and $\delta^{13} \mathrm{C}$ values of shells listed in Table 2.

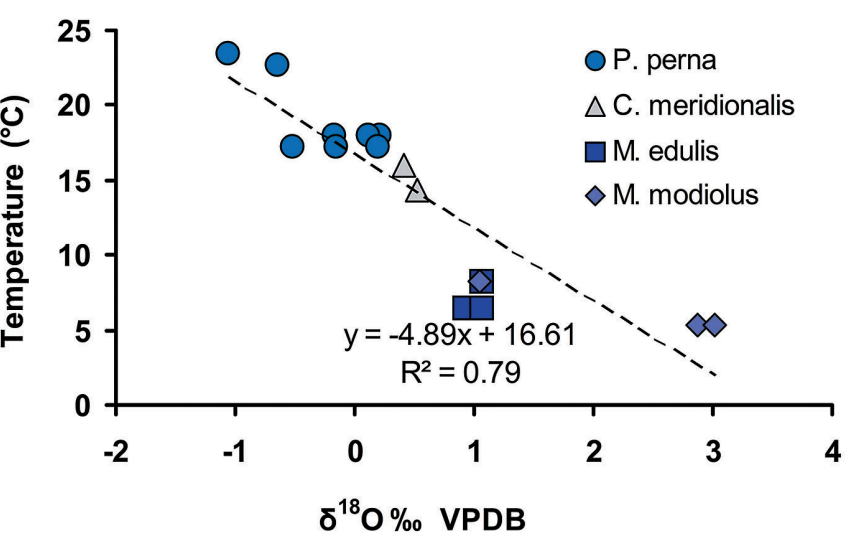

Fig. 3. Relationship between seawater temperature and $\delta^{18} \mathrm{O}$ values. Dots, Perna perna; triangles, Choromytilus meridionalis; squares, Mytilus edulis; diamonds, Modiolus modiolus.

There is a good inverse correlation in the diagram between the seawater temperature and the $\delta^{18} \mathrm{O}$ values of the Mytilidae shells, with a small scatter in spite of the shells having been collected over a comparatively long time and analysed in different laboratories. There is no clear indication of differences in the isotopic fractionation between the different Mytilidae species, as was shown for Choromytilus in the earlier study of shells from southern Africa (Talma et al., 1992). The line in the scatter diagram $\mathrm{T}=16.61-4.89 \times \delta^{18} \mathrm{O}$ (Fig. 3) for all Mytilidae shells is close to, but different 
from $\mathrm{T}=16.28( \pm 0.10)-4.57( \pm 0.15) \times\left(\delta^{18} \mathrm{O}_{c}-\right.$ $\left.\delta^{18} \mathrm{O}_{\mathrm{w}}\right)+0.06( \pm 0.06) \times\left(\delta^{18} \mathrm{O}_{\mathrm{c}}-\delta^{18} \mathrm{O}_{\mathrm{w}}\right)^{2}$, the one presented by Wanamaker et al. (2007) in the study of adult and juvenile Mytilus edulis mussels collected alive from northern Greenland and the Gulf of Maine, with a comparison with lines based on earlier equations of the relationship between temperature and $\delta^{18} \mathrm{O}$. Wanamaker et al. (2007) studied the Mytilus shells experimentally in buckets by controlling temperature and salinity of seawater, as well as seawater mixed with well water, whereby the obtained results about the relationship between temperature and $\delta^{18} \mathrm{O}$ was very accurate. The control of the effect of the temperature on the $\delta^{18} \mathrm{O}$ composition of the four different Mytilidae shell species used in the present study was naturally not equally accurate as in the experimental study by Wanamaker et al. (2007) because of the way in which the seawater temperatures of the coastal waters outside the beaches from which the shells were collected were used. The water temperature at some beaches with shallow water was most likely higher, especially during the summer months, than the temperature of the seawater further away from the beaches.

When bivalves close their valves under stress during colder months in winter, calcium carbonate from the inside is dissolved whereas the secretion of shell carbonate takes place throughout the year in the outer layer of the shells (Carter, 1980; Crenshaw, 1980). As a result, shells collected in late winter and early spring have a chalky, etched surface on the inside of the shell (Lutz \& Rhoads, 1980) as demonstrated by Talma et al. (1992) in a comparison of samples taken from the inner and outer layers of shells. The winter dissolution results in more negative annual mean $\delta^{18} \mathrm{O}$ values, towards warmer isotopic temperatures. If the summer growth rate is comparatively great it increases the bias even more. If this effect is taken into account in the presentation of the $\delta^{18} \mathrm{O}$ values of the Mytilidae shells from colder waters the results presented in the scatter diagram in Fig. 3 agree more closely with the correlation diagram presented by Wanamaker et al. (2007) for Mytilus.
The seasonal isotopic variations, based on samples from the outer layer of the shells, were analysed in five valves, of which those of Perna perna and Choromytilus meridionalis were from southern Africa, and the valves of Modiolus modiolus from Norway (Table 3), the variations being similar in all five shells analysed, representing the whole temperature range in the diagram in Fig. 3. The curve in Fig. 4 shows the variations of the $\delta^{18} \mathrm{O}$ values of Modiolus from Valset in Norway during a period of at least three years, this curve, however, not being as detailed as similar curves based on high-

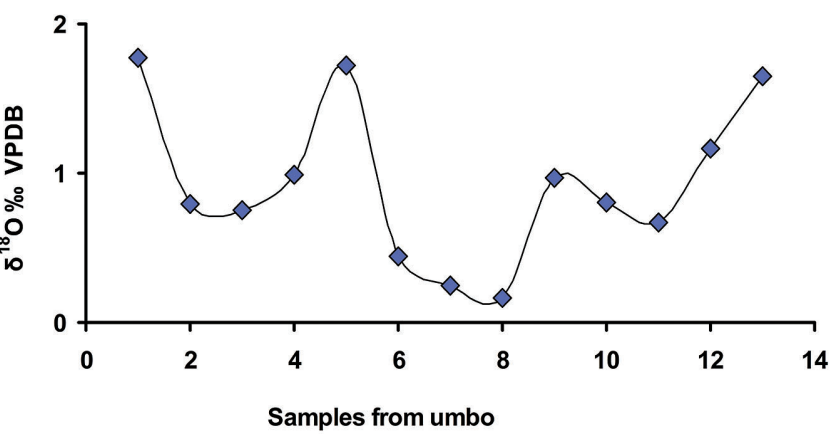

Fig. 4. Seasonal $\delta^{18} \mathrm{O}$ variations along valve of Modiolus modiolus from Valset, Norway. Samples are between 1.3 and $5.6 \mathrm{~cm}$ from umbo.

resolution records obtained as a result of technological advances permitting micro-sampling of molluscs (Wurster \& Patterson, 2001). The difference between the highest and lowest $\delta^{18} \mathrm{O}$ value in each shell is shown in Fig. 5 depicting the decrease in the isotopic temperatures from the Perna shell from southern Africa (1) to the Modiolus shell in Norway (5), i.e. from the negative $\delta^{18} \mathrm{O}$ values to the positive values. The results of the shells from southern Africa of Perna and Choromytilus were previously published by Talma et al. (1992) and compared with earlier studies of shells from southern Africa.

By using the linear regression equation (Fig. 3) the isotope temperatures for the minimum and maximum $\delta^{18} \mathrm{O}$ values of each of the five shells in Fig. 5 were calculated. The isotopic temperature amplitudes for the shells were close to the amplitudes calculated by the equation given for Mytilus (Wanamaker et al., 2007) and the amplitudes of 


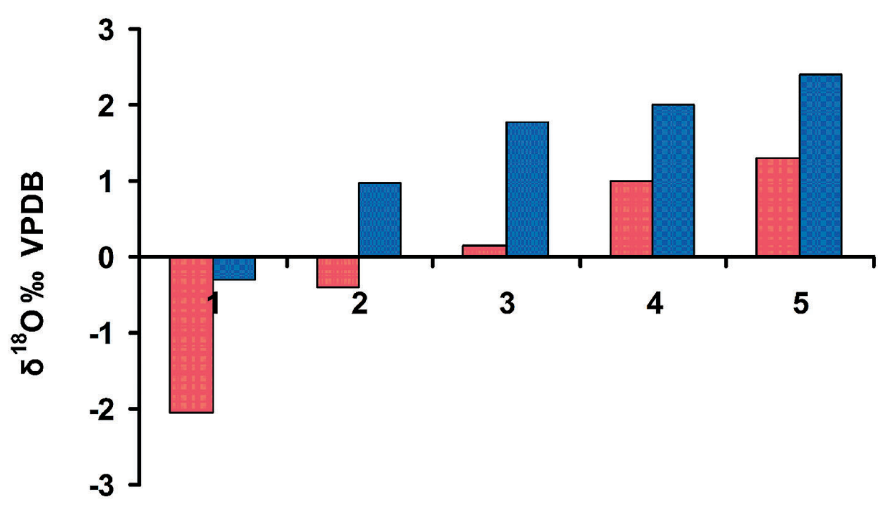

Fig. 5. Minimum and maximum $\delta^{18} \mathrm{O}$ values in shells listed in Table 3. 1 = Sordwana Bay, South Africa; 2 = Swakopmund, Namibia; 3 = Valset, Norway; 4 = Kjølnes, Norway; 5 = Havningberg, Norway.

the recorded seawater temperatures for the sites, except for Choromytilus from Swakopmund in $\mathrm{Na}$ mibia, where the recorded seawater amplitude is only 2 degrees, less than at the other sites (Table 4). The annual changes of the isotope temperature of the water at the beach from where the shells were collected were thus here greater than the recorded annual amplitude of the water outside the coast.

The results presented confirm in general earlier studies showing a good correlation between the seawater temperature and the $\delta^{18} \mathrm{O}$ values of the Mytilidae shells in agreement with the experimental results by Wanamaker et al. (2007). This enables the global use of the stable isotopes of the Mytilidae shells in palaeoclimatological/-oceanographical studies.

\section{Acknowledgements}

The authors want to thank Dr Sandra Gordillo for her professional support in the study of the shells and for the comments on the manuscript by the reviewers.

\section{References}

Carter, J.G. 1980. Environmental and biological controls of bivalve shell mineralogy and microstructure. In: Rhoads, D.C. \& Lutz, R.A. (eds.) Skeletal Growth of Aquatic Organisms. Plenum, New York, pp. 69-113.

Child, J. 1977. Australian sea shells. Periwinkle Books, Hong Kong, $80 \mathrm{pp}$.

Craig, H. 1965. The measurement of oxygen isotope paleotemperatures. In: Tongiorgi, E. (ed.) Stable isotopes in oceanographic studies and palaeotemperatures, Pisa, pp. 3-24.

Crenshaw, M.A. 1980. Mechanisms of shell formation and dissolution. In: Rhoads, D. C. \& Lutz, R. A. (eds.) Skeletal Growth of Aquatic Organisms. Plenum, New York, pp. $115-132$.

Christensen, J.M. \& Dance, S.P. 1980. Seashells, Bivalves of the British and Northern European Seas. Penguin Nature Guides, 124 pp.

Christensen, M.S. 1980. Sea-surface temperature charts for southern Africa. South African Journal of Science 76, 541546.

Coplen, T.B., Brand, W.A., Gehre, M., Gröning, M., Meijer, H.A.J, Torman, B. \& Verkourten, R.M. 2006. New guidelines for $\delta^{13} \mathrm{C}$ measurements. Analytical Chemistry 78, 2439-2441.

Dansgaard, W. \& Tauber, H. 1969. Glacier oxygen-18 content and Pleistocene ocean temperatures. Science 166, 499502.

Donner, J. \& Billström, K. 1988. Carbon and oxygen stable isotope values in recent and Eemian shells from the coast

Table 4. Temperature amplitudes calculated from shell $\delta^{18} \mathrm{O}$ values (using the linear regression equation in Fig. 3 and measured for sea water.

\begin{tabular}{lcccccc} 
Site & $\delta^{18} \mathrm{O}_{\min } \%$ & $\delta^{18} \mathrm{O}_{\max } \%$ & $\mathrm{~T}_{\max }{ }^{\circ} \mathrm{C}$ & $\mathrm{T}_{\min }{ }^{\circ} \mathrm{C}$ & $\mathrm{T}_{\text {shell }}$ ampl ${ }^{\circ} \mathrm{C}$ & $\mathrm{T}_{\text {sea water }}$ ampl ${ }^{\circ} \mathrm{C}$ \\
\hline & -2.06 & -0.31 & 26.68 & 18.13 & $8.6\left(8.2^{*}\right)$ & 5.0 \\
2 & -0.40 & 0.97 & 18.57 & 11.87 & $6.7(6.2 *)$ & 2.0 \\
3 & 0.16 & 1.78 & 15.83 & 7.91 & $7.9\left(7.2^{*}\right)$ & 7.9 \\
4 & 1.00 & 2.00 & 11.72 & 6.83 & $4.9(4.4 *)$ & 6.1 \\
5 & 1.30 & 2.40 & 10.25 & 4.87 & $5.4\left(4.8^{*}\right)$ & 4.8
\end{tabular}

$* \mathrm{~T}_{\text {shell }}(\mathrm{ampl})$ values in parentheses are calculated using the experimental equation for Mytilus edulis shells $\mathrm{T}=16.28( \pm 0.10)-$ $4.57( \pm 0.15) \times\left(\delta^{18} \mathrm{O}_{c}-\delta^{18} \mathrm{O}_{\mathrm{w}}\right)+0.06( \pm 0.06) \times\left(\delta^{18} \mathrm{O}_{c}-\delta^{18} \mathrm{O}_{\mathrm{w}}\right)^{2}$ given by Wanamaker et al. $(2007)$. 
of southern Africa. Palaeoecology of Africa 19, 261-268.

Donner, J. \& Jungner, H. 1981. Radiocarbon dating of marine shells from southeastern Australia as a means of dating relative sea-level changes. Annales Academiae Scientiarum Fennicae, Geologica-Geographica 131, 5-44.

Donner, J., Eronen, M. \& Jungner, H. 1977. The dating of Holocene relative sea-level changes in Finnmark, North Norway. Norsk geografisk Tidsskrift 31, 103-128.

Donner, J. \& Nord, A.G. 1986. Carbon and oxygen stable isotope values in shells of Mytilus edulis and Modiolus modiolus from Holocene raised beaches at the outer coast of the Varanger peninsula. North Norway. Palaeogeography, Palaeoclimatology, Palaeoecology 56, 35-50.

Epstein, S., Buchsbaum, R., Lowenstam, H.A. \& Urey, H.C. 1953. Revised carbonate-water isotopic temperature scale. Bulletin of the Geological Society of America 64, 13151326.

Kilburn, R. \& Rippey, E. 1982. Sea Shells of southern Africa. Macmillan, South Africa, 249 pp.

Lowenstam, H.A. 1954. Factors affecting the aragonite-calcite ratios in carbonate secreting marine organisms. Journal of Geology 62 (3), 284-322.

Lutz, R.A. \& Rhoads, D.C. 1980. Growth patterns within the molluscan shell. In: Rhoads, D.C. \& Lutz, R.A. (eds.) Skeletal Growth of Aquatic Organisms. Plenum, New York, pp. 203-254.

Midttun, L. 1975. Observation series on surface temperature and salinity in Norwegian coastal waters 1936-1970. Fisken og Havet B 5, Bergen, 51 pp.
Mook, W.G. 1971. Paleotemperatures and chlorinates from stable carbon and oxygen isotopes in shell carbonate. Palaeogeography, Palaeoclimatology, Palaeoecology 9, 245-263.

Mook, W.G. \& Vogel, J.C. 1968. Isotope equilibrium between shells and their environment. Science 159, 874-875.

Rubinson, M. \& Clayton, R.N. 1969. Carbon-13 fractionation between aragonite and calcite. Geochimica and Cosmochimica Acta 33, 997-1002.

Shackleton, N.J. 1967. Oxygen isotope analyses and Pleistocene temperatures re-assessed. Nature 215, 15-17.

Shackleton, N.J. 1987. Oxygen isotopes, ice volume and sea level. Quaternary Science Reviews 6, 183-190.

Talma, A.S., Donner, J.J. \& Ellis, S.D. 1992. Stable isotopic composition of marine shells along the southern African coast. South African Journal of Science 88, 491-504.

Wanamaker, A.D., Kreutz, K.J., Borns Jr., H.W., Introne, D.S., Feindel, S., Funder, S., Dawson, P.D. \& Barber, B.J. 2007. Experimental determination of salinity, temperature, growth and metabolic effects on shell isotope chemistry of Mytilus edulis collected from Maine and Greenland. Paleooceanography 22, PA2217, 1-12.

Wurster, C.M. \& Patterson, W.P. 2001. Seasonal variation in stable oxygen and carbon isotope values recovered from modern lacustrine freshwater molluscs: paleoclimatological implications for sub-weekly temperature records. Journal of Paleolimnology 26, 205-218. 